\title{
Pengaruh Edukasi Apoteker Terhadap Tahap Berhenti Merokok pada Mahasiswa Perokok Aktif Tahap Contemplation
}

\author{
Impact of Pharmacist Education on Smoking Cessation Behaviour in Active \\ Smoking Student in Contemplation Stage
}

\author{
Siswati*, Prih Sarnianto , Nurita Andayani \\ Universitas Pancasila \\ Corresponding author: Siswati: Email: siswatikind@gmail.com \\ Submitted: 12-11-2020 Revised: 16-12-2020
}

Accepted: 16-12-2020

\begin{abstract}
ABSTRAK
Kebiasaan merokok merupakan salah satu kebiasaan tidak sehat yang potensial menimbulkan penyakit kronis, seperti Diabetes Melitus tipe 2, penyakit kardiovaskular, penyakit jantung koroner, kanker paru dan penyakit pernafasan kronis. Masih banyaknya mahasiswa yang merokok, memerlukan pendekatan seperti adanya edukasi apoteker terhadap upaya berhenti merokok. Perilaku berhenti merokok terbagi menjadi beberapa tahapan, yaitu: tahap pre-contemplation, contemplation, preparation, action, maintenance dan relapse. Pada tahap contemplation, perokok telah berfikir serius untuk berhenti merokok. Intervensi edukasi oleh apoteker sebagai salah satu tenaga kesehatan, terutama pada perokok yang berada pada tahap contemplation merupakan hal penting yang dapat menunjang keberhasilan upaya berhenti merokok,sehingga mahasiswa perokok dapat berada pada tahap selanjutnya dari tahap contemplation. Penelitian ini memiliki desain studi quasi eksperimental pre-test dan post test dan pengumpulan data menggunakan metode purposive sampling. Penelitian ini bertujuan untuk mengetahui pengaruh edukasi apoteker terhadap perilaku berhenti merokok pada mahasiswa perokok aktif tahap contemplation. Dengan responden 43 mahasiswa perokok aktif tahap contemplation, hasil penelitian diuji dengan uji $t$ one pair, untuk melihat pengaruh edukasi apoteker terhadap perilaku berhenti merokok. Hasil penelitian menunjukkan, edukasi apoteker memberikan perubahan yang bermakna pada nilai Urica Scale tahap perilaku berhenti merokok, namun tidak merubah tahap berhenti merokok responden, dimana sebelum edukasi adalah contemplation, sesudah edukasi juga tetap berada di tahap contemplation. Kata kunci: Edukasi apoteker; perilaku berhenti merokok; Urica Scale; tahap contemplation
\end{abstract}

\begin{abstract}
Smoking habit is one of unhealthy habits potencially lead to cronic disease such as diabetes mellitus, cardiovascular, coronary heart disease, lung cancer, and other cronic respiration disease. Seen mostly student still smooking, need approachment of health worker as pharmacist taking an important role to educate as an effort of smoking cessation. Smoking cessation behavior, divided into several stages such as pre-contemplation, contemplation, preparation, action, maintenance dan relapse. At the stage contemplation,smokers have thought hard about quitting smoking. With intervention such as education by pahrmacist as a heatlh worker, specially to the active smokers at the stage contemplation, is one of the important things to support the success of smoking cessation. Expected with educational intervention, smoker student can be at an advance stage of the the stage contemplation. This study using a quasi eksperimental pre test dan post test study and data collection using purposive sampling method. This study aims to know the impact of pharmacist education on smoking cessation behaviour. Involving 43 responden, active smoker student of non pharmacist in contemplatin stage, the study result using $t$ one pair test to determine the impact of pharmacist education on smoking cessation behaviour. The result shows significant difference on respondent knowledge. Giving no significant difference on smoking cessation motivation and level of nicotine dependence and showing significant difference on smoking cessation behaviour mark but not untill change the stage of smoking behaviour respondent from contemplation stage. The cessation stage of
\end{abstract}


responden, ealier before pahrmacist education is contemplation, and remain in contemplation stage after the pahrmacist education.

Keywords: Pharmacist education; smoking cessation behaviour; Urica Scale; contemplation stage

\section{PENDAHULUAN}

Kebiasaan merokok merupakan salah satu kebiasaan tidak sehat yang sangat potensial menimbulkan penyakit-penyakit kronis seperti Diabetes Melitus tipe 2, penyakit kardiovaskular, penyakit Coronary Heart Disease (CHD), kanker paru dan penyakit pernafasan kronis. Perokok beresiko 15 kali lebih besar terkena kanker paru-paru dibandingkan dengan mereka yang tidak merokok dan penyebab 1 dari 3 kematian pada penyakit kardiovaskular (C. o. D. C. a. Prevention, 2017) (C. f. D. C. a. Prevention, 2017). Bahkan sekitar 50\% dari orang yang terkena penyakit karena mengkonsumsi rokok mengalami kematian dini. Selain menimbulkan bahaya medis yang mematikan, merokok juga memiliki bahaya psikologis seperti depresi, skizofrenia dan perilaku adiktif/ kecanduan (Service, 2014) (Eriksen \& Mackay, 2015).

Kematian akibat konsumsi rokok mencapai lebih dari 7 juta orang per tahunnya di dunia, di antaranya 6 juta lebih kematian akibat dari penggunaan rokok langsung dan sekitar 890.000 kematian merupakan kelompok nonperokok yang terpapar asap rokok (WHO, 2017).

Secara global, menurut data World Health Organization (WHO) pada 2015 lebih dari 1,1 miliar orang di dunia memiliki kebiasaan merokok. Di Indonesia, berdasarkan hasil Riset Kesehatan Dasar (Riskesdas) 2013, jumlah perokok kelompok umur $\geq 15$ tahun sebesar 64,9 persen pada laki-laki dan 2,1 persen pada perempuan. Prevalensi perokok di Indonesia menurut pendidikan, 26,7 persen adalah tamatan perguruan tinggi. Hal tersebut menjadi indikator bahwa kelompok berpendidikan tinggi juga masih mempunyai kecenderungan berperilaku tidak sehat, yaitu merokok. Keadaan tersebut menunjukkan bahwa tingginya tingkat pendidikan tidak selalu sejalan dengan pengetahuannya tentang bahaya merokok, sehingga masih menjalankan perilaku merokok (WHO, 2011) (Kesehatan, 2013).

Banyaknya bahaya merokok bagi kesehatan, membuat upaya berhenti merokok dari mahasiswa perokok perlu menjadi perhatian yang serius. Mahasiswa yang memiliki kesehatan fisik dan psikis yang baik dapat dengan optimal melakukan aktivitas akademi di kampus, sehingga mempunyai masa depan yang lebih baik dan berkontribusi bagi masa depan bangsa. Perilaku berhenti merokok menurut teori Transtheoritical Model (TTM) yang dikembangkan oleh Prochaska dan Di Clemente (1982) terbagi menjadi beberapa tahapan, yaitu: tahap pre-contemplation, contemplation, preparation, action, maintenance dan relapse. Tahap pre-contemplation adalah tahap dimana perokok tidak berniat untuk berhenti merokok. Intervensi langsung pada tahap ini menyebabkan peningkatan terhadap resistensi perubahan perilaku merokok. Selanjutnya, tahap contemplation merupakan tahap dimana perokok telah berfikir serius untuk berhenti merokok dan tahap preparation adalah tahap dimana perokok berniat melakukan perubahan dalam 30 hari atau dalam satu bulan berikutnya setelah tahap contemplation. Selanjutnya, tahap action, merupakan tahap dimana perokok telah melakukan perubahan perilaku selama kurang dari enam bulan. Pada tahap ini kemungkinan interaksi dengan lingkungan perokok perlu dihindari dan dieliminasi. Tahap maintenance ditandai dengan perubahan perilaku selama lebih dari enam bulan, sementara itu tahap relapse adalah tahapan dimana perokok kembali merokok, yang dapat terjadi pada proses mana pun dalam tahap penghentian (Ayse \& Eroglu, 2013).

Menurut teori Green (1991), perilaku dipengaruhi oleh tiga faktor, yaitu predisposisi, enforcing dan enabling. Pada perilaku berhenti merokok, sebagai faktor predisposisi adalah pengetahuan, dimana pengetahuan tentang bahaya merokok mempengaruhi perilaku merokok. Pada tahap contemplation, perokok telah berfikir serius untuk berhenti merokok. Adanya intervensi terhadap faktor predisposisi ini, seperti pemberian edukasi pada perokok oleh apoteker sebagai salah satu tenaga kesehatan, terutama pada perokok yang telah pada tahap contemplation merupakan hal penting yang dapat menunjang keberhasilan upaya berhenti merokok. Diharapkan dengan adanya intervensi edukasi, maka mahasiswa perokok dapat berada pada tahap selanjutnya dari tahap contemplation (Green \& WM, 2000). 
Pada pendekatan terhadap upaya berhenti merokok, peran dari tenaga kesehatan. seperti termasuk apoteker, sangat penting. Sebagai tenaga kesehatan, apoteker dapat berperan dalam mengedukasi untuk meningkatkan pengetahuan, membangun motivasi berhenti merokok dan menurunkan tingkat kecanduan nikotin. Penelitian Grassi et al (2014) menyatakan bahwa pemberian edukasi tentang rokok dan bahaya merokok bagi kesehatan terutama ketergantungan terhadap nikotin, akan meningkat kan pengetahuan dan kemampuan mahasiswa dalam mengatasi gangguan kecanduan nikotin. Hasil penelitian Marcie Wu et al (2015), menyatakan bahwa peran apoteker dalam memberikan edukasi tentang rokok pada remaja dapat meningkatkan pengetahuan dalam upaya perilaku berhenti merokok (Grassi et al., 2013) (Wu et al., 2013).

\section{METODOLOGI}

Berdasarkan tujuannya jenis penelitian ini merupakan penelitian terapan yang bertujuan untuk memberikan solusi atas permasalahan tertentu secara praktis. Berdasarkan metode penelitian desain yang digunakan dalam penelitian ini adalah Quasi experimental. Rancangan yang digunakan adalah pretest dan post test pada siklus penelitian.

Populasi dalam penelitian ini adalah seluruh mahasiswa Fakultas eksakta (non farmasi) dan non eksakta pada universitas daerah Jakarta Selatan. Responden adalah mahasiswa perokok aktif tahap contemplation, kemudian diberikan kuesioner URICA scale yang mengukur tahapan perilaku berhenti merokok. Kemudian mahasiswa yang berada pada tahap contemplation diberikan intervensi pemberian edukasi sebanyak tiga kali dan diminta mengisi kuesioner mengenai pengetahuan, tingkat kecanduan nikotin dan motivasi berhenti merokok. Pada akhir penelitian, responden diukur kembali tahap perilaku berhenti merokoknya dengan URICA Scale untuk mengetahui pengaruhnya terhadap tahap perilaku berhenti merokoknya.

Kriteria inklusi pada penelitian ini adalah mahasiswa perokok aktif (jurusan non Famasi) dan bersedia berpartisipasi dalam penelitian dengan mengisi informed consent. Kriteria eksklusi pada penelitian ini adalah mahasiswa fakultas farmasi dan mahasiswa pada setiap fakultas yang bukan perokok aktif, tidak merokok karena dalam pengobatan dan tidak bersedia untuk berpartisipasi dalam penelitian ini.

Teknik pengambilan sampel yang digunakan dalam penelitian ini adalah Purposive Sampling. Jumlah populasi pada penelitian ini sebanyak 7.764 orang. Jumlah sampel yang diperlukan dalam penelitian ini dihitung menggunakan rumus sampel minimal, sehingga diperoleh sampel sebesar 366 mahasiswa.

Kuesioner yang digunakan sebagai instrumen penelitian adalah kuesioner URICA scale yang digunakan untuk menentukan tingkat tahap berhenti merokok. Pengolahan data menggunakan aplikasi SPSS 20.

\section{HASIL DAN PEMBAHASAN \\ Sosiodemografi Responden}

Berdasarkan jumlah sampel sebanyak 366 mahasiswa, yang memenuhi persyaratan sebagai responden sebanyak 43 mahasiswa sebagai perokok aktif pada tahap Contemplation. Proses pengambilan sampel ditampilkan pada gambar 1 . Sedangkan data sosiodemografi responden terdapat pada tabel I.

Fakultas eksata di universitas tersebut, mayoritas mahasiswanya adalah laki-laki, sehingga secara sosiodemografi sebagian besar responden mahasiswa perokok aktif (58\%) adalah mahasiswa fakultas eksakta, yaitu mahasiswa fakultas Teknik. Fakultas non eksakta lainnya adalah responden gabungan dari fakultas lainnya di Universitas tersebut.

Usia pertama kali merokok responden, terlihat pada tabel I bahwa distribusi frekuensinya responden merokok pertama kali pada usia 12 - 15 tahun sebanyak 21 orang $(48,8 \%)$, berusia antara 16-18 tahun sebanyak 19 orang $(44,2 \%)$ dan merokok peratama kali pada usia 19-20 tahun sebanyak 3 orang (7,0\%). Hampir 93\% perokok mulai merokok ketika usianya belum mencapai 19 tahun, sesuai dengan data Riskedas pada tahun 2010 dan 2013 yang menunjukkan bahwa usia merokok pertama kali paling tinggi adalah pada kelompok umur 15-19 tahun (Kesehatan, 2013).

Umumnya orang mulai merokok sejak usia muda karena pada usia tersebut, pengetahuan akan dampak dan resiko mengenai bahaya adiktif rokok pada kesehatan sangat kurang. Hal yang menghawatirkan juga sesuai menurut US Department of Health and Human Service bahwa kebanyakan seseorang yang 


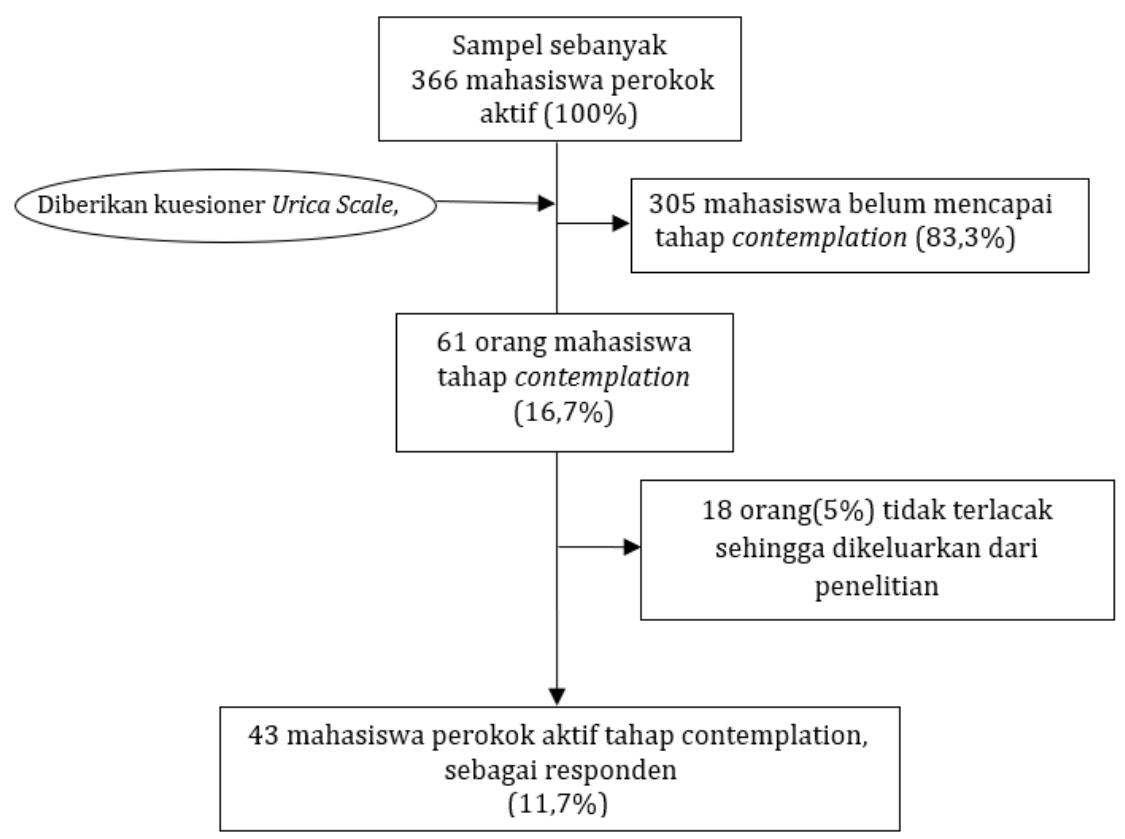

Gambar 1. Gambar pengambilan jumlah responden

memulai merokok sebelum usia 18 tahun, maka di usia dewasanya, frekuensi merokoknya dari perokok yang tidak setiap hari akan menjadi perokok harian atau perokok yang setiap hari selalu merokok (Service, 2014). Sedangkan studi yang dilakukan Kendler KS et al (2013) menyatakan bahwa awal mula usia merokok pada usia yang sangat muda akan meningkatkan beratnya dan lamanya pemakaian rokok dan penghentian penggunaan yang lebih sulit (WHO, 2017) (KS, Myers.J, M.I, \& X, 2013). Adanya pengaruh teman dalam pergaulan untuk merokok turut menjadi faktor awal mula merokok pada usia muda seperti yang dinyatakan pada studi yang dilakukan Neff LJet al (2015). Sedangkan sesuai penelitian Loke A.Y, WONG P.I ( 2010) peran lingkungan sekitar, adanya keluarga terdekat atau orang tua yang merokok juga merupakan pengaruh seseorang memulai merokok pada usia muda (Linda J. Neff et al., 2015) (AY \& YPI, 2011).

Berdasarkan jenis rokok yang dihisap, dari data distribusi frekuensi karasteristik responden pada tabel I, terlihat bahwa sebagian besar responden merokok dengan jenis rokok putih (filter) sebanyak 41 orang $(95,3 \%)$, dan jenis vape sebanyak 2 orang $(4,7 \%)$. Hampir 95\% mahasiswa merokok dengan jenis rokok putih (filter). Asumsi bahwa merokok jenis filter lebih aman dan mampu mengurangi dampak negatif yang disebabkan oleh rokok, membuat mayoritas responden merokok jenis filter. Diasumsikan lebih aman, karena rokok filter memiliki penyaring pada pangkal batang rokok dan memiliki kandungan nikotin yang lebih kecil, sehingga risiko yang ditimbulkan akan lebih kecil pula.

Namun bagaikan dua sisi mata uang, di sisi lain, penggunaan filter pada rokok sebenarnya juga berbahaya bagi konsumennya karena sisa filter terhirup yang dilapisi tar setelah tembakau dibakar, dapat masuk ke saluran pernafasan dan tahan terhadap biodegradasi juga bersifat karsinogenik. Kemudahan aksesibilitas dan ketersediaan rokok jenis filter yang sangat mudah dibandingkan dengan rokok jenis lainnya, juga menjadi alasan banyaknya pemakaian rokok jenis filter. Berbagai iklan rokok yang ada dimasyarakat juga menjadi alasan banyaknya pemakaian rokok, bahwa media memiliki pengaruh yang besar dan memegang peranan kunci dalam tren penggunaan rokok dimasyarakat. Dari data juga disebutkan ada 2 orang $(4,7 \%)$ mahasiswa yang menggunakan jenis vape, penggunaan vape walaupun belum sebanyak penggunaan rokok filter namun mulai banyak dikenal dimasyarakat. Menurut Mantey DS, et al marketing untuk penjualan vape melalui media sosial memungkinkan 
Tabel I. Sosiodemografi Responden Mahasiswa perokok aktif tahap Contemplation

\begin{tabular}{lcc}
\hline Karakteristik & Frekuensi & Proporsi \\
\hline Sosiodemografi & & \\
Usia (Tahun) & $19-24$ & - \\
Range umur & 20 & - \\
Median & 20,7 & - \\
Rata-rata & 24 & $55,8 \%$ \\
$19-20$ & 19 & $44,2 \%$ \\
$21-24$ & & \\
Jenis Kelamin & 39 & $90,7 \%$ \\
Laki-laki & 4 & $9,3 \%$ \\
Perempuan & & \\
Fakultas & 25 & $58,1 \%$ \\
Eksakta & 18 & $41,9 \%$ \\
Non Eksakta & & \\
Faktor Terkait Rokok & & $48,8 \%$ \\
Umur Merokok Pertama (Tahun) & 21 & $44,2 \%$ \\
$12-15$ & 19 & $7,0 \%$ \\
$16-18$ & 3 & \\
$19-20$ & & $11,6 \%$ \\
Lama merokok (Tahun) & 5 & $62,8 \%$ \\
$<3$ & 27 & $25,6 \%$ \\
$3-6$ & 11 & \\
$7-10$ & & $95,3 \%$ \\
Jenis Rokok & 41 & $4,7 \%$ \\
Filter & 2 & \\
Vape & & $51,2 \%$ \\
Jumlah Rokok Yang Dihisap & & $48,8 \%$ \\
Pertama Kali (batang) & 22 & \\
$1-10$ & 21 & \\
$11-20$ & & \\
\hline
\end{tabular}

Tabel II. Hasil Uji Kolmogorov Smirnov Test

\begin{tabular}{lll}
\hline & urica pretest & urica postest \\
\hline Test Statistic &, 114 &, 134 \\
Asymp. Sig. (2-tailed) & $.193^{\mathrm{c}}$ & $.052^{\mathrm{c}}$ \\
\hline
\end{tabular}

Tabel III. Hasil Uji Kolmogorov Smirnov Test

\begin{tabular}{ccc}
\hline \multicolumn{3}{c}{ Pre-Post Test Urica } \\
\hline $\mathrm{t}$ & -7.325 \\
$\mathrm{Sig}$. & .000 \\
\hline
\end{tabular}

pemasarannya yang akan makin meluas di masa mendatang (WHO, 2011) (Mantey, Cooper, Clendennen, Pasch, \& Perry, 2016).

Berdasarkan durasi lamanya responden merokok sampai saat mengikuti penelitian, didapatkan data bahwa sebanyak 5 responden $(11,6 \%)$ telah merokok selama kurang dari tiga tahun, sebanyak 27 responden $(62,8 \%)$ telah merokok selama 3-6 tahun, dan sebanyak 11 responden $(25,6 \%)$ telah merokok selama 7-10 tahun.

Tahap Perilaku Berhenti Merokok Responden Sebelum dan Sesudah Edukasi

Sebelum edukasi, 43 orang responden adalah mahasiswa perokok aktif yang berada pada tahap perilaku contemplation sesuai hasil kuesioner Urica Scale yang diberikan pada 
Tabel IV. Nilai Urica Scale Responden Sebelum Edukasi dan Sesudah Edukasi

\begin{tabular}{cccccc}
\hline No & Pre test & Post test & No & Pre test & Post test \\
\hline $\mathbf{1}$ & $\mathbf{9 , 1 4}$ & $\mathbf{9 , 1 4}$ & 23 & 9,43 & 10,00 \\
2 & 8,57 & 9,71 & 24 & 9,29 & 9,86 \\
3 & 9,29 & 9,86 & 25 & 9,71 & 10,29 \\
4 & 9,43 & 9,57 & $\mathbf{2 6}$ & $\mathbf{9 , 2 9}$ & $\mathbf{9 , 2 9}$ \\
5 & 10,29 & 10,43 & 27 & 9,14 & 10,00 \\
$\mathbf{6}$ & $\mathbf{9 , 7 1}$ & $\mathbf{9 , 7 1}$ & 28 & 9,00 & 9,71 \\
7 & 9,86 & 10,14 & 29 & 9,14 & 9,29 \\
8 & 8,14 & 9,29 & 30 & 9,71 & 9,86 \\
9 & 9,00 & 10,71 & 31 & 9,29 & 9,14 \\
10 & 8,71 & 9,71 & $\mathbf{3 2}$ & $\mathbf{8 , 8 6}$ & $\mathbf{8 , 8 6}$ \\
11 & 10,00 & 10,14 & 33 & 8,14 & 9,29 \\
12 & 8,86 & 9,86 & 34 & 9,00 & 10,14 \\
13 & 8,71 & 9,57 & $\mathbf{3 5}$ & $\mathbf{8 , 5 7}$ & $\mathbf{8 , 5 7}$ \\
14 & 9,00 & 10,29 & 36 & 9,00 & 8,43 \\
15 & 8,29 & 9,71 & 37 & 9,57 & 9,86 \\
16 & 9,14 & 10,14 & $\mathbf{3 8}$ & $\mathbf{1 0 , 4 3}$ & $\mathbf{1 0 , 4 3}$ \\
17 & 9,14 & 9,57 & 39 & 9,29 & 10,43 \\
$\mathbf{1 8}$ & $\mathbf{8 , 7 1}$ & $\mathbf{8 , 7 1}$ & 40 & 8,29 & 9,71 \\
19 & 9,43 & 9,57 & 41 & 9,43 & 10,29 \\
20 & 8,29 & 8,86 & 42 & 9,43 & 10,57 \\
21 & 9,00 & 9,71 & 43 & 9,14 & 10,29 \\
22 & 9,29 & 9,86 & & & \\
\hline
\end{tabular}

responden sebelum intervensi edukasi. Setelah intervensi edukasi akhir, yaitu edukasi tahap III, dilakukan posttest dengan memberikn kuesioner Urica Scale untuk mengukur apakah ada responden yang mengalami perubahan tahap perilaku berhenti merokoknya yang semula adalah tahap contemplation.

Setelah dilakukan pengukuran, pada tabel IV terlihat tidak adanya perubahan tahap perilaku berhenti merokok, walaupun ada perubahan nilai ukuran hasil urica, namun semua responden masih dalam tahap perilaku berhenti merokok contemplation. Pada nilai Urica Scale terlebih dahulu di lakukan pengujian distribusi datanya dengan Uji Kolmogorov Smirnov. Pada tabel II dari uji tersebut didapatkan hasil Sig lebih besar dari 0,05 maka dapat dinyatakan data tersebut terdistribusi normal. Selanjutnya untuk mengetahui apakah perubahan nilai Urica Scale sebelum dan sesudah edukasi ada perbedaan yang bermakna, diuji dengan uji statistik $t$ one pair, hasil hasil nilai sig. adalah 0,000 , nilai sig. lebih kecil dari 0,005 menyatakan bahwa nilai Urica Scale sebelum dan sesudah Edukasi ada perbedaan yang bermakna atau signifikan.

Dari Tabel III Setelah diuji dengan uji $t$ one pair hasilnya adalah adanya perubahan yang bermakna antara Nilai Urica Scale saat pre-test dan nilai Urica Scale saat post test. Terlihat dari data pada tabel IV, hanya ada $7(16,28 \%)$ responden yang nilainya tetap sebelum dan sesudah edukasi. Responden yang nilai Urica Scale nya menurun hanya ada $2(4,7 \%)$ orang, yang nilai Urica Scale nya adalah 9,29 menurun menjadi 9,14 dan yang nilai Urica Scale nya 9,00 menjadi 8,43. Responden yang mengalami peningkatan nilai Urica Scale ada 34 responden $(79,07 \%)$, hal ini menandakan lebih dari sebagian besar responden mengalami peningkatan nilai Urica Scale nya.

Adanya peningkatan nilai Urica Scale, mengindikasikan adanya harapan akan perubahan tahap perilaku merokok dari responden, dimana hal tersebut sangat banyak faktor mempengaruhinya. Terlihat dari hasil data lain dari responden, dimana pengetahuan responden yang mengalami peningkatan yang bermakna setelah edukasi, adanya motivasi berhenti merokok yang baik pada sebagian besar responden, juga tingkat kecanduan nikotinnya yang banyak masih dalam kategori rendah, semua hal tersebut bisa menjadi faktor yang mempengaruhi terjadinya peningkatan nilai Urica Scale pada 34 (79,07\%) responden yang sesuai dengan beberapa penelitian yang 
dilakukan oleh beberapa penelitian, antara lain yang dilakukan oleh Luciana $\mathrm{R}$ et al (Chaaya et al., 2013).

Penelitian yang dilakukan oleh Greenhalg et al (2016) juga menyatakan ada 7 faktor yang dapat memprediksi sukses atau gagalnya usaha untuk berhenti merokok, antara lain tingkat kecanduan nikotinnya, lamanya merokok, orang-orang yang berada di lingkungan sekitarnya, psikologi dari perokok, motivasi, terapi yang sesuai dan norma sosial yang berlaku (Greenhalgh, 2016).

Perbedaan bermakna adanya perubahan untuk nilai pre dan postnya para responden, namun terlihat dari data bahwa perubahan tersebut belum mengubah tahapan perilaku berhenti merokok responden, walaupun kecenderungannya tinggi karena sebagian besar mengalami peningkatan pada nilai Urica Scale nya. Semua nilai Urica Scale responden masih dalam kisaran 8-10, yang berarti masih dalam tahap contemplation. Hal tersebut menandakan masih perlu waktu yang cukup bagi responden untuk siap berpindah ke tahap berhenti merokok selanjutnya.

\section{KESIMPULAN}

Edukasi apoteker memberikan perubahan yang bermakna pada nilai Urica Scale tahap perilaku berhenti merokok, namun tidak merubah tahap berhenti merokok responden, dimana sebelum edukasi adalah contemplation, sesudah edukasi juga tetap berada di tahap contemplation

\section{DAFTAR PUSTAKA}

AY, L., \& YPI, W. (2011). Smoking Among Young Children In Hong Kong. Influence Of Parental Smooking. Journal of Advance Nursing, 66(12), 2659-2670.

Ayse, K., \& Eroglu, K. (2013). The Transtheoretical Model Use For Smoking Cessation. International Associates of Social Science Research-IASSR.

Chaaya, M., Alameddine, M., Nakkash, R., Afifi, R. A., Khalil, J., \& Nahhas, G. (2013). Students' attitude and smoking behaviour following the implementation of a university smoke-free policy: a crosssectional study. BMJ Open, 3(4).

Eriksen, M., \& Mackay, J. (2015). The tobacco atlas, Fifth Edition. Atlanta: The American Cancer Society.
Grassi, M. C., Baraldo, M., Chiamulera, C., Culasso, F., Raupach, T., Ferketich, A. K., ... Nencini, P. (2013). Knowledge about Health Effects of Cigarette Smoking and Quitting among Italian University Students. BioMed Research International Journal, 4(7), 423-429.

Green, \& WM, K. (2000). Health Promotion Planing. An Educational and Environmental Aproach.second edition. USA: Mayfield Publishing Company.

Greenhalgh, E., Jenkins S., Stillman, S., \& Ford, C. (2016). Factors That Predict Succes or Failure In Quit Attemps. Retrieved from Melbourne:

Kesehatan, K. (2013). Hasil Riset Kesehatan Dasar (Riskesdas) 2013. Retrieved from Jakarta:

KS, K., Myers.J, M.I, D., \& X, C. (2013). Early Smooking Onset and Risk Of Subquent Nicotine Dependence. Study Am J Psychiatry, 170, 408-413.

Linda J. Neff, P., René A. Arrazola, M., Ralph S. Caraballo, P., Catherine G. Corey, M., Shanna Cox, M., Brian A. King, P., . . . Corinne G. Husten, M. (2015). Frequency of Tobacco Use Among Middle and High School Students - United States, 2014. Retrieved from

Mantey, D. S., Cooper, M. R., Clendennen, S., Pasch, K., \& Perry, C. L. (2016). ECigarette Marketing Exposure is Associated with E-cigarette Use among U.S. Youth. J Adolesc Health, 58(6), 686690.

Prevention, C. f. D. C. a. (2017). What Are the Risk Factors for Lung Cancer? Retrieved from

https://www.cdc.gov/cancer/lung/basic _info/risk_factors.htm

Prevention, C. o. D. C. a. (2017). Smooking and Tobacco Use. Retrieved from https://www.cdc.gov/tobacco/basic_inf ormation/health_effects/heart_disease/i ndex.htm

Service, U. D. o. H. a. H. (2014). Preventing Tobacco Use among Youth and Young Adults: We Can Make the Next Generation Tobacco-Free. A Report of the Surgeon General. Atlanta

WHO. (2011). Global Adult Tobacco Survey. Global Adult Tobacco Survey (GATS) Indonesia Report 2011. Retrieved from 
Pengaruh Edukasi Apoteker Terhadap Tahap Berhenti Merokok pada Mahasiswa

WHO. (2017). Prevalence of Tobacco Smoking. (factsheets). WHO

Wu, M.-T. M., Shen, W.-C., Chang, J.-C., Chiang, Y.C., Chen, H.-M., \& Chen, H.-Y. (2013). The
Impact of a Pharmacist-Conducted Interactive Anti-Smoking Education Program on the Attitudes and Knowledge of High School Students. Scientific Research, 4(7), 423-429. 